\title{
Histomorfometrik duodenum kelinci jantan setelah diberi pakan komersial disuplementasi minyak hati ikan kod
}

\author{
Histomorphometric of duodenum in male rabbits after fed commercial feed \\ supplemented by cod liver oil
}

\author{
Ni Gusti Ayu Manik Ermayanti ${ }^{1 *}$, Ni Wayan Sudatri ${ }^{1}$, Ni Nyoman Wirasiti ${ }^{1}$, I Gusti Ayu Manik Widhyastini ${ }^{2}$ \\ 1)Program Studi Biologi, Fakultas Matematika dan Ilmu Pengetahuan Alam, Universitas Udayana \\ ${ }^{2)}$ Jurusan Biologi, Fakultas Matematika dan Ilmu Pengetahuan Alam, Universitas Nusa Bangsa, Bogor
}

*Email: manikermayanti@unud.ac.id

Diterima 18 Maret 2021 Disetujui 27 Juni 2021

\section{INTISARI}

Minyak ikan adalah sumber asam lemak tidak jenuh ganda rantai panjang (PUFA) yang dapat digunakan sebagai pakan tambahan pada pakan komersial untuk meningkatkan produktivitas kelinci jantan. PUFA berfungsi dalam berbagai proses fisiologi, di antaranya dalam sisem pencernaan. Penelitian ini bertujuan untuk mengetahui histomorfometrik duodenum kelinci jantan setelah diberi pakan komersial disuplementasi minyak hati ikan kod. Rancangan percobaan yang digunakan adalah Rancangan Acak Lengkap (RAL) dengan empat perlakuan pakan, yaitu pakan komersial tanpa minyak hati ikan kod (P0) sebagai kontrol, pakan komersial disuplementasi minyak hati ikan kod 3\% (P1), 4,5\% (P2), dan 6\% (P3). Masing-masing perlakuan terdiri atas lima ekor kelinci lokal jantan sebagai ulangan dan perlakuan diberikan mulai kelinci berumur 1-3 bulan. Parameter yang diamati adalah panjang vili, lebar vili, kedalaman kripta, dan ketebalan tunika mukosa duodenum kelinci jantan. Data yang diperoleh dianalisis dengan Anova dan jika berbeda nyata diuji lanjut dengan DMRT. Hasil penelitian menunjukkan bahwa suplementasi minyak hati ikan kod pada pakan komersial berbeda nyata $(p<0,05)$ terhadap parameter histomorfometrik (panjang vili, lebar vili, kedalaman kripta, dan ketebalan tunika mukosa) duodenum kelinci jantan. Dapat disimpulkan bahwa suplementasi minyak hati ikan kod pada pakan komersial dapat meningkatkan histomorfometrik duodenum kelinci lokal jantan.

Kata kunci: asam lemak, duodenum, kelinci, minyak hati ikan kod

\begin{abstract}
Fish oil is a source of long-chain polyunsaturated fatty acids (LCPUFA) that can be used as supplementary feed in commercial feed to increase male rabbit productivity. PUFAs function in various physiological processes, including in the digestive system. This study aimed to determine the histomorphometrics of male rabbits duodenum after fed commercial feed supplemented by cod liver oil. The experimental design used was a Completely Randomized Design (CRD) with four feed packages, namely commercial feed without cod liver oil (P0) as a control, commercial feed supplemented with cod liver oil 3\% (P1), 4.5\% (P2) and $6 \%$ (P3). Each consists of five male local rabbits as replicates and given starting female rabbits 1-3 months. The parameters observed were villi height, villi width, crypt depth, and tunica mucosa thickness of the duodenum in male rabbits. The data obtained were analyzed with Anova and if significantly different were further tested with DMRT. The results showed that cod liver oil supplementation in commercial feed was
\end{abstract}


significantly different $(\mathrm{p}<0.05)$ to the histomorphometric parameters (villi height, villi width, crypt depth, and thickness of the tunica mucosa) of the duodenum in male rabbits. Can be concluted that supplementation of cod liver oil in commercial feed can increase the histomorphometrics of male local rabbits duodenum.

Keywords: fatty acid, duodenum, rabbit, cod liver oil

\section{PENDAHULUAN}

Lemak adalah salah satu komponen dalam pakan yang sangat penting untuk kehidupan karena sebagai penyumbang energi terbanyak. Polyunsaturated fatty acid (PUFA) sebagai sumber asam lemak tidak jenuh esensial telah menjadi perhatian para ahli gizi dalam beberapa tahun terakhir (El-Gogary et al., 2014). Asam lemak alpha linolenic acid (ALA, C18:3) adalah prekursor untuk omega 3 (n-3). Omega 3 adalah asam lemak tidak jenuh ganda rantai panjang (LC-PUFA) yang rantai hidrokarbonnya mempunyai 2 atau lebih ikatan ganda. Ikatan ganda pertama yang dimiliki n-3 LC-PUFA berada pada posisi karbon ke-3 dari ujung rantai metil $\left(-\mathrm{CH}_{3}\right)$. Selanjutnya, n-3 LC-PUFA dengan melibatkan enzim desaturase dan enzim elongase akan dikonversi menjadi EPA (eicosapentaeoic acid / C20:5n-3) dan DHA (docosahexaaenoic acid/ C22:6n-3) (Gurr et al., 2016).

PUFA adalah asam lemak esensial yang dibutuhkan oleh tubuh yang tidak dapat disintesis oleh tubuh oleh karena itu harus tersedia dalam pakan (Spector \& Kim, 2015). Asam lemak esensial tersebut memiliki efek fisiologis yang luas (Ristic-Medic et al., 2013), di antaranya mengatur berbagai proses sistem vaskular dan imun (Auger et al., 2016), otak dan sistem saraf (Fenton et al., 2013). Selain itu, PUFA merupakan komponen penting dari lapisan ganda fosfolipid membran (Samuelsson, 2012), merupakan prekursor dari sintesis mediator lipid bioaktif yaitu prostaglandin, tromboksan, leukotrien, dan lipoksin (Gurr et al., 2016), memiliki peran antiinflamasi (Vangaveti et al., 2016) dan berhubungan dengan kesehatan usus (Menni et al., 2017) serta untuk pengobatan radang usus besar (Turner et al., 2011).
Sumber utama n-3 PUFA yang tinggi dapat diperoleh dari minyak ikan. Beberapa hasil penelitian dari minyak ikan yang kaya akan LCPUFA telah diuji untuk kesehatan pada hewan. Penggunaan minyak ikan gindara sebagai anti hiperlipidemia pada tikus putih (Majid et al., 2019). Penggunaan minyak ikan hati kod untuk memperbaiki profil lipid kelinci jantan (Ermayanti et al., 2018 ). Penggunaan minyak ikan salmon untuk meningkatkan sistem imun pada ayam (Pilevar et al., 2011).

Integritas morfologi usus dapat digunakan sebagai dasar untuk mengevaluasi fisiologis normal organ tersebut. Sel-sel epitel usus berasal dari dasar kripta bermigrasi ke atas dan bergerak sepanjang permukaan vili ke ujung vili untuk mengganti sel-sel epitel yang terkelupas (Sherwood et al., 2013). Vili yang lebih panjang dapat meningkatkan penyerapan nutrisi dalam usus halus karena tersedianya luas permukaan yang lebih besar (de Oliviera et al., 2013). Salah satu parameter yang dapat digunakan untuk mengetahui kinerja pertumbuhan kelinci adalah melakukan pengamatan pada struktur histologi usus. El-Gogary et al., (2014) melaporkan penggunaan minyak ikan taraf 1 dan 1,5\% dapat meningkatkan panjang vili duodenum kelinci NZW yang sedang dalam pertumbuhan. Berdasarkan hal tersebut maka dilakukan penelitian yang bertujuan untuk mengetahui histomorfometrik duodenum kelinci lokal jantan setelah diberi pakan komersial disuplementasi minyak hati ikan kod.

\section{BAHAN DAN METODE}

\section{Hewan coba}

Hewan coba yang digunakan adalah kelinci lokal jantan sebanyak 20 ekor, umur satu bulan, 
dengan rerata berat badan 210-212 g. Kelinci diperoleh dari Desa Riang Gede, Kecamatan Tabanan, Kabupaten Tabanan. Kelinci dipelihara dalam kandang besi sistem baterai individual dengan ukurang 45x30x40 $\mathrm{cm}$. Prosedur percobaan dengan menggunakan kelinci sebagai hewan percobaan telah dinyatakan Laik Etik (Ethichal Clearance) oleh Komisi Etik Penggunaan Hewan dalam Penelitian dan Pendidikan, Fakultas Kedokteran Hewan Universitas Udayana, Denpasar.

\section{Pakan}

Pakan yang digunakan adalah pelet pakan komersial yang diproduksi oleh P.T. Japfa Comfeed Indonesia dan diperoleh dari toko pakan ternak di Beringkit Mengwi Badung. Bahan penyusun pakan komersial adalah jagung kuning, dedak, bungkil kedelai, molasses dan minyak sawit. Minyak hati ikan kod yang digunakan adalah emulsi minyak hati ikan kod yang diproduksi oleh P.T. Merck Tbk, Jakarta dan diperoleh dari apotik di Tabanan. Pakan dan minum diberikan secara ad libitum.

\section{Rancangan percobaan}

Rancangan percobaan yang digunakan adalah Rancangan Acak Lengkap (RAL). Dua puluh ekor kelinci lokal jantan diacak menjadi empat perlakuan pakan termasuk kontrol dan masingmasing perlakuan dengan lima ulangan. Masingmasing perlakuan pakan yang diujicobakan adalah P0: kontrol (pakan komersial tanpa suplementasi minyak hati ikan kod) ; P1: pakan komersial disuplementasi minyak hati ikan kod 3\% ; P2: pakan komersial disuplementasi minyak hati ikan kod 4,5\% dan P3: pakan komersial disuplementasi minyak hati ikan kod $6 \%$. Perlakuan pakan berlangsung selama 2 bulan, dimulai pada saat kelinci berumur 1-3 bulan.

\section{Pembuatan sediaan histologi duodenum}

Sehari setelah perlakuan berakhir, kelinci dikorbankan dan selanjutnya dibedah untuk dibuat sediaan histologi duodenum. Pembuatan sediaan histologi duodenum dilakukan dengan metode parafin, fiksatif NBF $10 \%$, tebal sayatan $5 \mu \mathrm{m}$ dan pewarnaan H-E (Alturkistani et al., 2016).

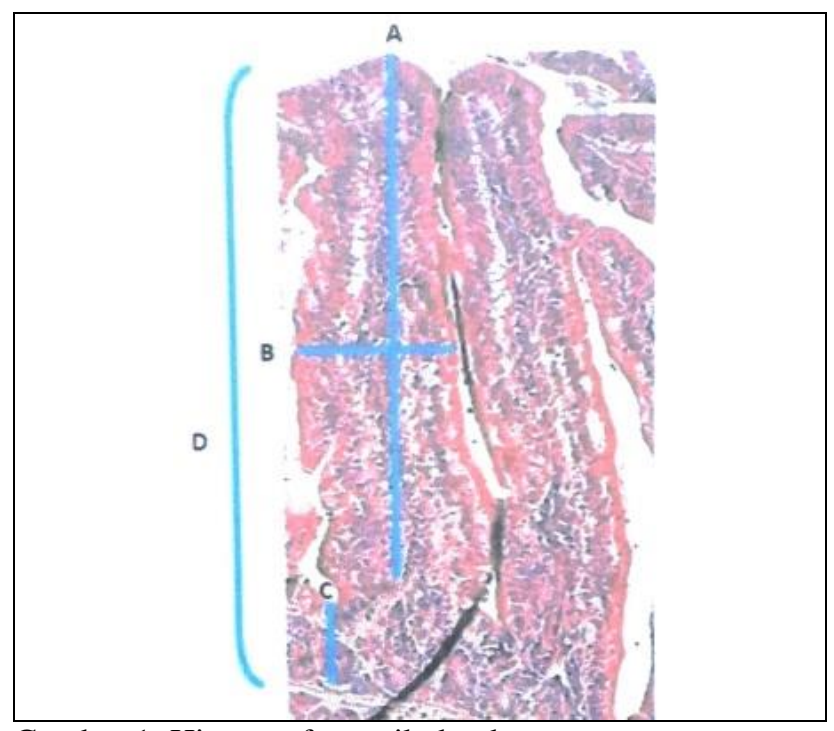

Gambar 1. Histomorfometrik duodenum.

Keterangan: A (panjang vili), B (lebar vili), C (kedalaman kripta), D (ketebalan tunika mukosa)

\section{Parameter penelitian}

Pengamatan parameter histomorfometrik duodenum dilakukan dengan mengukur panjang vili, lebar vili, kedalaman kripta, dan ketebalan tunika mukosa duodenum kelinci lokal jantan (Gambar 1). Pengamatan histomorfometrik duodenum dihitung 5 lapang pandang menggunakan kamera mikroskop XSZ-107BN optilab dengan perbesaran 100x.

\section{Analisis data}

Data dianalisis secara statistik dengan uji normalitas menggunakan uji KolmogorofSmirnof, selanjutnya data dianalisis dengan One Way Anova dan uji lanjut DMRT. Analisis data menggunakan bantuan program SPSS for Windows versi 22.

\section{HASIL}

Hasil analisis statistik histomorfometrik duodenum kelinci jantan setelah diberi pakan komersial disuplementasi minyak hati ikan kod dapat dilihat pada Tabel 1 . 
Tabel 1. Histomorfometrik duodenum kelinci lokal jantan setelah diberi pakan komersial disuplementasi minyak hati ikan kod

\begin{tabular}{ccccc}
\hline \multirow{2}{*}{ Perlakuan } & \multicolumn{3}{c}{ Histomorfometrik duodenum } \\
\cline { 2 - 5 } & Panjang vili $(\mu \mathrm{m})$ & Lebar vili $(\mu \mathrm{m})$ & Kedalaman kripta $(\mu \mathrm{m})$ & Ketebalan tunika mukosa $(\mu \mathrm{m})$ \\
\hline P0 & $3079,0 \pm 97,9 \mathrm{a}$ & $637,0 \pm 9,6 \mathrm{a}$ & $1041,0 \pm 2,2 \mathrm{a}$ & $4122,2 \pm 1,5 \mathrm{a}$ \\
P1 & $3179,0 \pm 96,6 \mathrm{a}$ & $640,6 \pm 9,2 \mathrm{a}$ & $1051,2 \pm 1,9 \mathrm{a}$ & $4232,6 \pm 1,9 \mathrm{a}$ \\
P2 & $3668,0 \pm 92,9 \mathrm{~b}$ & $1265,0 \pm 91,9 \mathrm{~b}$ & $1530,8 \pm 2,6 \mathrm{~b}$ & $5202,0 \pm 5,1 \mathrm{~b}$ \\
P3 & $3660,4 \pm 92,5 \mathrm{~b}$ & $1260,6 \pm 94,9 \mathrm{~b}$ & $1525,4 \pm 2,3 \mathrm{~b}$ & $5189,0 \pm 7,3 \mathrm{~b}$
\end{tabular}

Keterangan: Nilai yang diikuti oleh huruf yang berbeda pada kolom yang sama menunjukkan hasil yang berbeda nyata ( $<<0,05)$. P0(kontrol), P1(3\%), P2(4,5\%), P3(6\%).

Berdasarkan hasil pengamatan yang tercantum pada Tabel 1 tampak bahwa pelakuan suplementasi minyak hati ikan kod pada pakan komersial memberikan pengaruh yang nyata $(\mathrm{p}<0,05)$ terhadap rerata panjang vili, lebar vili, kedalaman kripta, dan ketebalan tunika mukosa duodenum kelinci jantan. Uji lanjut juga menunjukkan hasil yang berbeda nyata $(\mathrm{p}<0,05)$ antar perlakuan pakan. Kelinci yang mendapat perlakuan pakan_P1 (3\%) tidak berbeda nyata dengan kelinci P0 (kontrol), kelinci yang mendapat perlakuan pakan P2 $(4,5 \%)$ dan P3 (6\%) berbeda nyata dengan kelinci P0 (kontrol) sedangkan antar perlakuan P2 dan P3 tidak berbeda nyata. Rerata histomorfometrik duodenum kelinci lokal jantan tertinggi terdapat pada kelinci P2 (4,5\%). Hal ini menunjukkan suplementasi minyak hati ikan kod pada perlakuan P2 yaitu taraf 4,5\% paling berpengaruh terhadap peningkatan rerata panjang vili, lebar vili, kedalaman kripta, dan ketebalan tunika mukosa duodenum kelinci jantan. Nilai persentase yang didapat dari kelinci P2 adalah panjang vili $(3668,0 \mu \mathrm{m})$, lebar vili $(1265,0 \mu \mathrm{m})$, kedalaman kripta $(1530,8 \mu \mathrm{m})$, dan ketebalan tunika mukosa $(5202,0 \mu \mathrm{m})$ lebih tinggi dari kelinci P0 (kontrol).

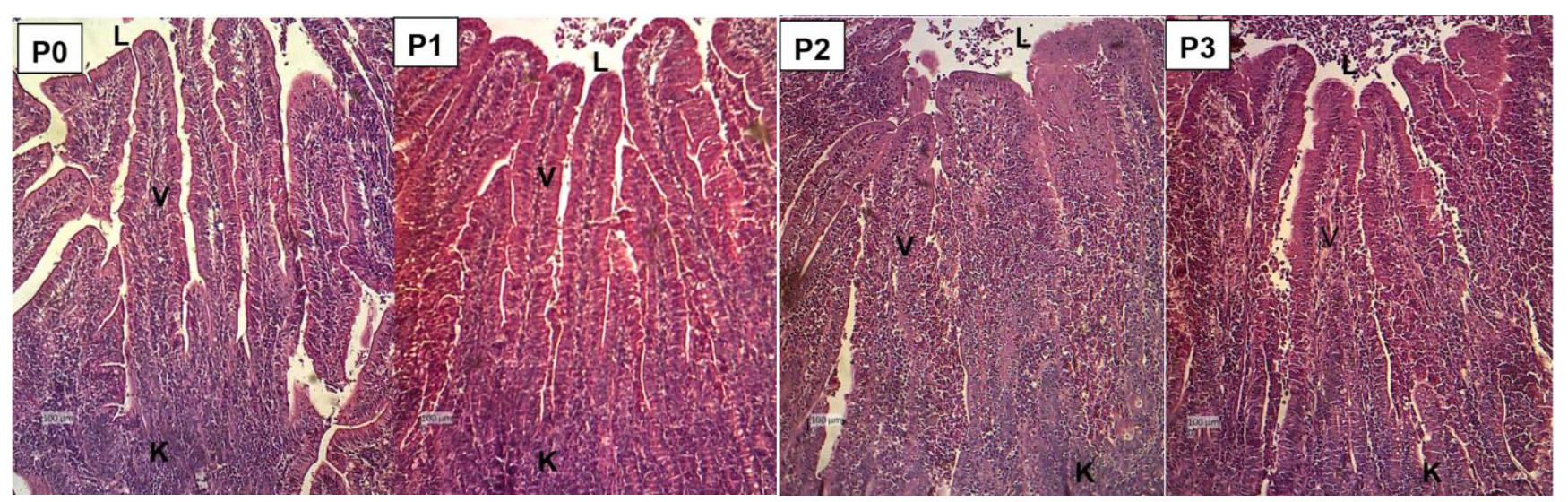

Gambar 2. Histomorfometrik duodenum kelinci lokal jantan setelah diberi pakan komersial disuplementasi minyak hati ikan kod. P0 (Kontrol), P1(3\%), P2 (4,5\%), P3 (6\%), Lumen (L), Vili (V), Kripta (K). Pewarnaan: HE. Perbesaran:100x

Gambar 2 menunjukkan histomorfometrik duodenum kelinci lokal jantan setelah diberi pakan komersial disuplementasi minyak hati ikan kod. Gambar yang diambil adalah gambar yang paling mewakilkan untuk masing-masing perlakuan. Pada gambar tampak vili yang menonjol ke lumen duodenum kelinci. Vili merupakan penjuluran mukosa (epitel serta lamina propria). Di antara vilus-vilus terdapat kripta yang merupakan invaginasi mukosa dan kripta akan bersambung dengan epitel vili. Pada P0 (kontrol) tampak vili lebih pendek dari perlakuan P1 (3\%), P2 (4,5\%) dan P3(6\%). Selain vili yang lebih pendek, pada P0 (kontrol) juga menunjukkan lebar vili dan kedalaman kripta yang lebih pendek dari perlakuan P1 (3\%), P2 
(4,5\%) dan P3 (6\%). Peningkatan histomorfometrik tampak jelas pada perlakuan P2 (4,5\%) diikuti oleh perlakuan P3 (6\%), P2 (3\%), P0 (kontrol).

\section{PEMBAHASAN}

Pemberian pakan komersial yang disuplementasi minyak hati ikan kod merupakan suatu cara yang diharapkan dapat meningkatkan produktivitas ternak kelinci lokal jantan. Pada penelitian ini, suplementasi minyak hati ikan kod dengan taraf yang berbeda pada pakan komersial memberikan pengaruh terhadap histomorfometrik duodenum kelinci jantan lokal, yaitu terhadap panjang vili, lebar vili, kedalaman kripta, dan ketebalan tunika mukosa.

Proses pencernaan berfungsi untuk menguraikan makanan dari yang strukturnya kompleks diubah menjadi satuan-satuan yang lebih kecil sehingga dapat diabsorpsi dan usus halus (duodenum, jejunum, dan ileum) merupakan tempat berlangsungnya sebagian besar pencernaan dan absorpsi (Sherwood et al., 2013). Perkembangan duodenum kelinci adalah penting khususnya mukosa (vili) untuk absorpsi, submukosa (kelenjar) untuk pencernaan enzimatik. Mukosa usus halus harus mampu mengatur absorpsi tidak hanya untuk mendapatkan nutrisi dan mempertahankan homeostasis, tetapi juga untuk memfasilitasi pertumbuhan yang cepat dari individu yang sedang tumbuh (Elnasharty et al., 2013). Selain itu, mukosa yang melapisi lumen usus halus beradaptasi sempurna untuk melaksanakan fungsi absorptifnya karena luas permukaan yang sangat besar. Vili adalah tonjolan-tonjolan mikroskopik berbentuk jari pada pernukaan usus halus yang dapat meningkatkan luas permukaan 10 kali lipat (Sherwood et al., 2013). Semakin luas permukaan vili usus semakin besar peluang terjadinya absorbsi dari saluran pencernaan (de Oliviera et al., 2013).

Pada penelitian ini didapatkan hasil bahwa suplementasi minyak hati ikan kod mampu meningkatkan panjang vili, lebar vili, kedalaman kripta duodenum kelinci jantan sehingga terjadi peningkatkan absorpsi zat-zat makanan oleh usus. Peningkatan panjang vili dan kedalaman kripta akan diikuti oleh peningkatan ketebalan tunika mukosa duodenum kelinci jantan. Terjadinya peningkatan histomorfometrik duodenum kelinci jantan kemungkinan disebabkan oleh kandungan minyak hati ikan kod yaitu n-3 LC-PUFA mempunyai kemampuan untuk meningkatkan aktivitas mitosis di kripta sehingga terjadi pergantian enterosit yang lebih cepat dan mukosa usus dapat berdiferensiasi dengan baik. Hal ini, sesuai dengan sifat fungsional PUFA yang telah dilaporkan. PUFA mempunyai pengaruh pada beberapa aktivitas biologis, di antaranya sebagai pengaturan struktur dan fungsi membran sel, pengaturan jalur pensinyalan intraseluler, aktivitas faktor transkripsi dan ekspresi gen, serta regulasi mediator lipid bioaktif (Zarate et al., 2017). PUFA dapat terlepas dari fosfogliserida membran sel oleh stimulasi fosfolipase PLA-2. Selanjutnya, PUFA dapat mengatur ekspresi gen secara langsung atau melalui zat di dalam sitosol. PUFA adalah prekursor untuk pembawa pesan kedua dari senyawa eikosanoid dan dokosanoid. Dengan demikian, berperan dalam inflamasi, imun, vaskular, saraf dan pertumbuhan sel (Kalish et al., 2012 ; Bazinet \& Laye, 2014 ; Luchtman \& Song, 2013).

Penelitian yang sesuai dilakukan oleh ElGogary et al. (2014) yang menyatakan suplementasi minyak hati ikan kod (cod liver oil) dapat meningkatkan panjang vili dan kedalaman kripta duodenum kelinci dibandingkan dengan kontrol. Rajput et al. (2013) menyatakan kedalaman kripta menunjukkan kecepatan perbaikan jaringan pada vili saat terjadi pengelupasan. Menurut Sherwood et al. (2013) sel-sel baru yang terus-menerus dibentuk di bagian dasar kripta bermigrasi ke atas vili untuk mengganti sel-sel tua yang terkelupas. Sel-sel baru terbentuk karena tingginya aktivitas mitosis di kripta. Dengan demikian, terjadinya peningkatan histomorfometrik duodenum kelinci pada penelitian ini kemungkinan disebabkan oleh meningkatnya aktivitas mitosis di kripta. 
Pendapat yang sama juga dilaporkan oleh Lisley et al., (2005) vili yang lebih panjang dan lebih luas berkaitan erat dengan peningkatan aktivitas mitosis sel sehingga dapat meningkatkan penyerapan nutrisi dalam usus kecil karena luas permukaan yang lebih besar tersedia untuk fungsi ini. Sebaliknya, vili usus yang lebih pendek mengganggu absorpsi di usus, menurunkan kemampuan absorpsi hewan, dan menghasilkan kinerja yang lebih rendah. Lisnahan et al., (2019) menyatakan vili usus merupakan tempat absorpsi nutrien, semakin tinggi dan semakin lebar vili usus serta ukuran kedalaman kripta semakin besar maka nutrien yang dicerna dan diabsorbsi semakin meningkat yang akhirnya berdampak pada pertumbuhan organ-organ tubuh. Hidayat et al.,(2016) yang melakukan penelitian pada puyuh jantan juga melaporkan semakin panjang vili dan semakin dalam kripta maka semakin luas bidang absorbsi nutrisi sehingga proses transportrasi nutrisi semakin optimal pada puyuh jantan.

Epitel usus tersusun dari vili dan kripta untuk memberikan luas permukaan mukosa yang maksimal untuk absorpsi nutrisi. Oleh karena itu, absorpsi nutrien dan efisiensi absorpsi bergantung pada integritas mukosa usus (Zeitz et al., 2015). Secara keseluruhan, vili yang lebih panjang memberikan permukaan mukosa yang lebih banyak, sedangkan kripta yang lebih dalam menunjukkan pergantian enterosit yang lebih cepat (Choct, 2009). Dengan demikian vili yang panjang dan kripta yang dalam menunjukkan mukosa usus dapat berdiferensiasi baik dengan permukaan absorpsi yang maksimal.

Selain itu, meningkatnya morfometrik duodenum kelinci pada penelitian ini kemungkinan disebabkan oleh fungsi LC-PUFA sebagai antiinflamasi sehingga dapat meningkatkan status kesehatan kelinci. Wei et al., (2014) melaporkan LC-PUFA memiliki efek pada imunitas melalui perannya dalam sintesis eikosanoid, meredakan reaksi inflamasi dan mengurangi tingkat komplikasi inflamasi dan menurut Menni et al., (2017) LC-PUFA berhubungan erat dengan kesehatan usus. Ezema \& Eze (2012) melaporkan salah satu paling penting untuk kesehatan usus adalah memberikan pakan terbaik yang memenuhi kebutuhan nutrisi untuk usia dan tahap produksi tertentu. Pakan yang tepat untuk berbagai tahap perkembangan fisiologis sangat penting dan ternak memerlukan suplemen makanan dalam berproduksi. Dari hasil penelitian yang telah dilakukan oleh Kowalska et al., (2007) mendapakan bahwa dengan suplementasi minyak ikan $4 \%$ pada ransum kelinci NZW yang sedang tumbuh selama 90 hari dapat menghasilkan berat badan akhir yang lebih tinggi dibandingkan kontrol.

Kelinci yang sedang tumbuh mudah mengalami stres dan mortalitas. Maertens et al., (2005) menyatakan kelinci sering mengalami enteropati epizootik dan melaporkan terjadi penurunan mortalitas pada kelinci yang disapih dengan diberi pakan yang kaya n-3. Lebih lanjut dikatakan, ini mungkin berkaitan dengan peningkatan sistem imun pada kelinci yang diberi pakan yang kaya n-3. Selain itu, suplementasi minyak hati ikan kod pada pakan komersial dapat meningkatkan histomorfometrik kelinci jantan dikarenakan minyak ikan yang digunakan dalam penelitian ini berbentuk emulsi. Dibandingkan dengan minyak ikan standar, konsumsi suplemen minyak ikan emulsi dapat menghasilkan peningkatan absorpsi total n-3 PUFA karena dapat meningkatkan kinerja usus melalui aktivitas lipase pankreas pada LC-PUFA (Raatz et al., 2009). Akan tetapi, pemberian n-3 yang tinggi juga dapat bersifat toksik pada hewan. Konieczka et al., (2017) melaporkan pemberian pakan tinggi asam lemak n-3 pada ayam dapat mengarah pada stres oksidatif karena dapat menyebabkan terjadinya peroksida lipid.

\section{KESIMPULAN}

Suplementasi minyak hati ikan kod pada pakan komersial dapat meningkatkan histomorfometrik duodenum kelinci jantan, yaitu dapat meningkatkan panjang vili, lebar vili, kedalaman kripta, dan ketebalan tunika mukosa duodenum kelinci lokal jantan. 


\section{UCAPAN TERIMAKASIH}

Penulis mengucapkan terima kasih kepada Lembaga Penelitian dan Pengabdian Kepada Masyarakat (LPPM) Universitas Udayana yang telah menyediakan dana Penelitian Unggulan Program Studi (PUPS). Penulis juga mengucapkan terima kasih kepada Fakultas Matematika dan Ilmu Pengetahuan Alam (FMIPA) Universitas Udayana yang telah memfasilitasi sehingga penelitian ini dapat diselesaikan dengan tepat waktu.

\section{DAFTAR PUSTAKA}

Alturkistani HA, Tashkandi FM, Mohammedsaleh ZM. 2016. Histological stains:a literature review and case study. Glob. J. Health Sci. 8(3): 72-79.

Auger C, Said A, Nguyen PN, Chabert P, Idriskhodja N, Schini-kerth VB. 2016. Potential of food and natural products to promote endothelial and vascular health. $J$. Cardiovasc. Pharmacol. 68: 11-18.

Bazinet RP, Laye S. 2014. Polyunsaturated fatty acids and their metabolites in brain function and disease. Nat. Rev. Neurosci. 15: 771-785

Choct M. 2009. Managing gut health through nutrition. Br. Poult. Sci. 50: 9-15.

de Oliveira MC, da Silva DM, Dias DMB. 2013. Effect of feed restriction on organs and intestinal mucosa of growing rabbits. $R$. Bras. Zootec. 42(7): 530-534.

El-Gogary MR, El-Moghazy MM, El-Atrsh A, Tousson E. 2014. Effect of fish oil administration on growth performance, some blood parameters, duodenum and caecum histology of growing rabbits. Egypt. J. Basic Appl. Phsiol. 13: 45-56.

Elnasharty MAI, Abou-Ghanema, Sayed-Ahmed A, Elnour AA. 2013. Mucosal- submucosal changes in rabbit duodenum during development. World Academy of Science, Engineering and Technology 76: 500-508.

Ermayanti NGAM, Oka IGL, Mahardika IG, Suyadnya IP. 2018. Profil lipid kelinci (Lepus sp.) jantan lokal yang diberi pakan komersial disuplementasi minyak hati ikan kod. Jurnal Biologi Udayana 22(1): 7-12.
Ezema C, Eze C. 2012. Determination of The effect of probiotic (Saccharomyces cerevisiae) on growth performance and hematological parameters of rabbits. Comaparative Clinical Pathology 21: 73-76.

Fenton JI, Hord NG, Ghosh S. 2013. Immunomodulation by dietary long chain omega-3 fatty acids and the potential for adverse health outcomes. Prostaglandins Leukot Essent Fatty Acids 89: 379-390.

Gholami H, Chamani M, Towhidi A, Fazeli MH. 2011. Improvement of semen quality in holstein bulls during heat stress by dietary supplementation of omega-3 fatty acids. Int. J. Fertil. Steril. 4(4): 160-167.

Gurr MI, Harwood JL, Frayn KN, Murphy DJ, Michell RH. 2016. Lipids: Biochemistry, Biotechnology and Health, $6^{\text {th }}$ ed., Wiley/Blackwell: Oxford, UK.

Hidayat SCM, Harimurti S, Yusiati LM. 2016. Pengaruh suplementasi probiotik bakteri asam laktat terhadap histomorfologi usus dan performan puyuh jantan. Buletin Peternakan 40(2): 101-106.

Ilsley SE, Miller HM, Kamel C. 2005. Effects of dietary quillaja saponin and curcumin on the performance and immune status of weaned piglets. J. Anim. Sci. 83: 82-88.

Kalish BT, Fallon EM, Puder M. 2012. A tutorial on fatty acid biology. JPEN J. Parenter Enteral Nutr. 36: 380-388.

Konieczka P, Barszcz M, Choct M, Smulikowska S. 2018. The interactive effect of dietary n6:n-3 fatty acid ratio and vitamin E level on tissue lipid peroxidation, DNA damage in intestinal epithelial cells, and gut morphology in chickens of different ages. Poult. Sci. 97(1): 149-158.

Kowalska D, Bielanski P. 2007. Effect of Dietary fish oil supplement on rearing performance of young rabbits and quality of their meat. Pol. J. Food Nutr. Sci. 57(3): 63-66.

Lisnahan CV, Wihandoyo, Zuprizal, Harimurti S. 2019. Morfologi usus ayam kampung umur 20 minggu yang disuplementasi dl-metionin dan 1-lisin HCL dalam pakan. Journal of Tropical Animal Science and Technology 1(1): 14-21.

Luchtman DW, Song C. 2013. Cognitive enhancement by omega-3 fatty acids from child-hood to old age: findings from animal 
and clinical studies. Neuropharmacology. 64: $550-565$.

Majid NC, Simanjuntak P, Suwarno T. 2019. Uji aktivitas anti hiperlipidemia minyak ikan gindara (Lepidocybium flavobrunneum) pada tikus putih jantan dewasa galur wistar. Jurnal Ilmu Kesehatan 18(3):77-81.

Menni C, Zierer J, Pallister T, Jackson MA, Long T, Mohney RP, Steves CJ, Spector TD, Valdes AM. 2017. Omega-3 fatty acids correlate with gut microbiome diversity and production of $\mathrm{N}$-carbamylglutamate in middle aged and elderly women. Sci. Rep. 7:11079.

Maertens L, Aerts JM, De Brabander DL. 2005. Effect of a diet rich in n-3 fatty acids on the performances and milk composition of does and the viability of their progeny. In Proc.: 1lème J. Rech. Cunicoles, Bolet G. (Ed.) ITAVI, publ., Paris, France, 29\&30: 205208.

Pilevar M, Arshami JAAD, Golian A, Basami MR. 2011. Effects of dietary n-6: n-3 ratio on immune and reproductive systems of pullet chicks. Poult. Sci. 90:1758-1766.

Raatz SK, Redmon JB, Wimmergren N, Donadio JV, Bibus DM. 2009. Enhanced absorption of omega-3 fatty acids from emulsified compared with encapsulated fish oil. J. Am. Diet Assoc. 109: 1076-1081.

Rajput N, Muhammad N, Yan R, Zhong X, Wang T. 2013. Effect of dietary supplementation of curcumin on growth performance, intestinal morphology and nutrients utilization broiler chicks. J. Japan Poult Sci. Assoc. 50: 44-52

Ristic-Medic D, Vucic V, Takic M, Karadzic I, Glibetic M. 2013. Polyunsaturated fatty acids in health and disease. J. Serb. Chem. Soc. 78(9): 1269-1289.

Samuelsson B. 2012. Role of basic science in the development of new medicines: examples from the eicosanoid field. J. Biol. Chem. 287: 10070-10080.

Sherwood L, Klandorf H, Yancey P. 2013. Animal Physiology: From Genes to Organism. $2^{\text {rd }}$ ed. Publisher by Brooks Cole, Cengange Learning.

Spector A, Kim H-Y. 2015. Discovery of essential fatty acids. J. Lipid Res. 56:11-21.

Turner D, Shah PS, Steinhart AH. 2011. Maintenance of remis-sion in inflammatory bowel disease using omega-3 fatty acids (fish oil): a systematic review and meta-analyses. Inflamm Bowel Dis. 17: 336-345.

Vangaveti VN, Jansen H, Kennedy RL, Malabu UH. 2016. Hydroxyoctadecadienoic acids: oxidised derivatives of linoleic acid and their role in inflammation associated with metabolic syndrome and cancer. Eur. J. Pharmacol., 785: 70-76.

Wei Z, Wang W, Chen J, Yang D, Yan R, Cai Q. 2014. A prospective, randomized, controlled study of omega-3 fish oil fat emulsion-based parenteral nutrition for patients following surgical resection of gastric tumors. Nutrition Journal 13: 25-36.

Yu H-N, Zhu J, Pan W-S, Shen S-R, Shan W-G, Das UN. 2014. Effects of fish oil with a high content of n-3 polyunsaturated fatty acids on mouse gut microbiota. Archives of Medical Research 45(3): 195-200.

Zarate R, El Jaber-Vazdekis N, Tejera N, Perez JA, Rodriguez C. 2017. Significance of long chain polyunsaturated fatty acids in human health. Clin Transl Med. 6(1): 25.

Zeitz JO, Fennhoff J, Kluge H, Stangl GI, Eder K. 2015. Effects of dietary fats rich in lauric and myristic acid on performance, intestinal morphology, gut microbes, and meat quality in broilers. Poult. Sci. 94: 2404-2413. 